\title{
Machine Selection for a Textile Company with CRITIC and MAUT Methods
}

\author{
Engin Karakış ${ }^{1 *}$ \\ 1* Sivas Cumhuriyet University, Faculty of Economics and Administrative Sciences, Department of Econometrics, Sivas, Turkey, (ORCID: 0000-0003-1271-1742), \\ ekarakis@cumhuriyet.edu.tr
}

(First received 13 September 2021 and in final form 30 November 2021)

(DOI: $10.31590 /$ ejosat.994697)

ATIF/REFERENCE: Karakış, E. (2021). Machine Selection for a Textile Company with CRITIC and MAUT Methods. European Journal of Science and Technology, (27), 842-848.

\begin{abstract}
The main purpose of the companies is to make a profit and to ensure that this profitability is continuous. In this context, the selection of the machines used by the companies in production is an important issue. Businesses have to choose the most suitable machine to reduce their costs and produce efficiently. For this reason, the decision of machine selection is also very important for textile enterprises. Machine selection in textile enterprises is a Multi-Criteria Decision problem in which a large number and contradictory criteria are taken into account. In this study, machine selection will be made with CRITIC and MAUT methods for a textile company. In the study, the weights of the decision criteria that are effective in the decision-making were determined by the CRITIC method. Then, the machine selection was made by evaluating the alternatives with the MAUT method. According to the results of the study, CRITIC and MAUT methods were evaluated as integrally applicable to machine selection.
\end{abstract}

Keywords: Multi-Criteria Decision Making, CRITIC, MAUT, Flat Knitting Machine Selection.

\section{CRITIC ve MAUT Yöntemleri ile Bir Tekstil İşletmesi İçin Makine Seçimi}

Öz

İşletmelerin temel amacı kâr etmek ve bu kârlılığın sürekli olmasını sağlamaktır. Bu bağlamda işletmelerin üretimde kullandığı makinelerin seçimi stratejik bir karardır. İşletmeler maliyetlerini düşürmek ve verimli üretim yapabilmek için en uygun makineyi seçmek zorundadırlar. Bu nedenle makine seçim kararı tekstil işletmeleri için de çok önemlidir. Tekstil işletmelerinde makine seçimi, çok sayıda ve birbiriyle çelişen kriterin dikkate alındığı çok kriterli bir karar problemidir. Bu çalışmada bir tekstil işletmesi için CRITIC ve MAUT yöntemleri ile makine seçimi yapılmıştır. Çalışmada öncelikle makine seçimi kararı vermede etkili olan karar kriterlerinin ağırlıkları CRITIC yöntemi ile belirlenmiştir. Daha sonra MAUT yöntemi ile alternatifler değerlendirilerek makine seçimi yapılmıştır. Çalışma sonuçlarına göre CRITIC ve MAUT yöntemlerinin makine seçiminde bütünleşik olarak uygulanabilir olduğu değerlendirilmişsir.

Anahtar Kelimeler: Çok Kriterli Karar Verme, CRITIC, MAUT, Düz Örgü Makinesi Seçimi.

\footnotetext{
*Corresponding Author: ekarakis@ @umhuriyet.edu.tr
} 


\section{Introduction}

Businesses can ensure their continuity by constantly making profits and growing. Otherwise, they will have difficulty maintaining their presence in increasing global competition. A significant amount of capital is allocated for machinery and equipment, especially in production enterprises, and these fixed capital investments significantly affect operating profitability. For this reason, businesses make production plans, including planning machinery and equipment, to achieve low-cost and efficient production. Choosing a machine that will reduce costs and increase productivity when planning production is essential for ensuring operating profitability. In this context, the selection of machinery and equipment, transport vehicles, and other construction machinery used in production are extremely important and strategic decisions for enterprises.

The machine selection problem is one of the important decision-making problems for production companies. Incorrect machine selection can negatively affect the performance of the production system. The speed, quality, and cost of production depend significantly on the machines used. The machine selection decision is a difficult and long process, as well as requires advanced knowledge and expertise (Ertuğrul, 2007:171).

The choice of machines used in production is a situation that requires the consideration of numerous and contradictory criteria. Multi-Criteria Decision Making(MCDM) methods have been developed to solve decision problems where there are many and conflicting criteria. MCDM methods offer scientific and effective solutions to decision problems where there are many contradictory criteria. MCDM methods achieve the decision- maker to choose the best alternative by optimizing multiple criteria(Zeydan etc, 2020:418-429).

In this study, the choice of a flat knitting machine for a textile enterprise was realized by CRITIC(CRiteria Importance Through Intercriteria Correlation) and Maut(Multi-Attribute Utility Theory) methods which are one of the MCDM methods.

In the study, the weights of the criteria were determined by the CRITIC method, alternatives were evaluated by the MAUT method and ranking and selection were made with the help of hand results. There are not many studies in the Turkish literature in which CRITIC and MAUT methods are used together. In addition, there are no studies using CRITIC and MAUT methods on textile machine selection in the literature. This study will contribute to the Turkish literature in this aspect.

This article is divided into five sections. After the introduction section containing information about the decision problem in the study, the second section contains a literature review. In the third section, the method of work and data are given and in the fourth section, the application of flat knitting machine selection is given. The results obtained in the last part of the study were examined and discussed.

\section{Literature review}

There are many studies in the literature on the selection of machines used in the production systems of companies. It is seen that CRITIC and MAUT methods are used in solving many decision problems, especially in the fields of engineering and social science. In the literature review section, firstly, studies in which CRITIC and MAUT methods are used together and together with different methods are included. These studies are shown in Table 1.

Table 1. Literature review on CRITIC, MAUT methods, and other MCDM methods.

\begin{tabular}{|c|c|c|c|}
\hline Researcher & Year & Methods & Decision Problem \\
\hline Boscovic et al. & 2021 & CRITIC and ARAS & Mobile network provider operator selection \\
\hline Li et al. & 2020 & $\begin{array}{l}\text { Fuzzy DEMATEL, Entropy, } \\
\text { and VIKOR }\end{array}$ & Machine tool selection \\
\hline Yürük and Orhan & 2020 & $\begin{array}{l}\text { CRITIC, ENTROPİ and } \\
\text { MAUT }\end{array}$ & $\begin{array}{l}\text { Financial performance analysis } \\
\text { manufacturing industry sub-sectors }\end{array}$ \\
\hline $\begin{array}{l}\text { Vargün, Doğan and } \\
\text { Bal }\end{array}$ & 2020 & MAUT & Personnel selection for the accounting unit \\
\hline Orhan and Aytekin & 2020 & CRITIC, MAUT, and SAW & $\begin{array}{l}\text { Comparison of the R\&D performances of } \\
\text { Turkey and the countries that recently } \\
\text { joined the EU }\end{array}$ \\
\hline Eş and $\mathrm{Koc}$ & 2020 & $\begin{array}{l}\text { ENTROPİ, MAUT and } \\
\text { VIKOR }\end{array}$ & Supplier selection \\
\hline Stirbanovic et al. & 2019 & VIKOR and TOPSIS & Evaluation of flotation machines \\
\hline Yalçın and Karakaş & 2019 & CRITIC and EDAS & $\begin{array}{l}\text { Corporate sustainability performance } \\
\text { analysis for an energy company }\end{array}$ \\
\hline $\begin{array}{l}\text { Özdağoğlu and } \\
\text { Çirkin }\end{array}$ & 2019 & OCRA, MAUT & Electronic device selection \\
\hline Akın & 2019 & $\begin{array}{l}\text { Entropy-ROV and CRITIC- } \\
\text { ROV }\end{array}$ & Bed edge border sewing machine selection \\
\hline Bulgu & 19 & MAUT and CRITIC & ection \\
\hline d Cengiz & 2018 & and EVAMIX & Choosing a laptop for a bu \\
\hline $\begin{array}{l}\text { Gunawan and } \\
\text { Ramadhan }\end{array}$ & 2018 & MAUT & Performance evaluation of employees \\
\hline Ulutaş & 2017 & EDAS & $\begin{array}{l}\text { Choosing a sewing machine for a textile } \\
\text { workshop }\end{array}$ \\
\hline
\end{tabular}




\begin{tabular}{|c|c|c|c|}
\hline Adalı and Işık & 2017 & CRITIC and MAUT & Contract manufacturer selection \\
\hline $\begin{array}{l}\text { Chan, Suen, and } \\
\text { Chan }\end{array}$ & 2006 & AHP and MAUT & Selection of resolution model in disputes \\
\hline $\begin{array}{l}\text { Özceylan, Kabak and } \\
\text { Dağdeviren }\end{array}$ & 2016 & $\begin{array}{l}\text { Fuzzy AAS and } \\
\text { PROMETHEE }\end{array}$ & CNC machine selection \\
\hline $\mathrm{Wu}, \mathrm{Ahmad}$, and $\mathrm{Xu}$ & 2016 & Fuzzy VIKOR & CNC machine tool selection \\
\hline Ertuğrul and Öztaş & 2015 & MOORA and TOPSIS & Selection of Sewing machine \\
\hline $\begin{array}{l}\text { Diakoulaki, } \\
\text { Mavrotas and } \\
\text { Papayannakis }\end{array}$ & 1995 & CRITIC & Performance analysis of companies \\
\hline Ertuğrul & 2007 & Fuzzy AHP & Machine selection in the textile business \\
\hline
\end{tabular}

\section{Material and Method}

This study aims to select a flat knitting machine for a textile company. The steps of the decision model applied in the study are shown in Figure 1.
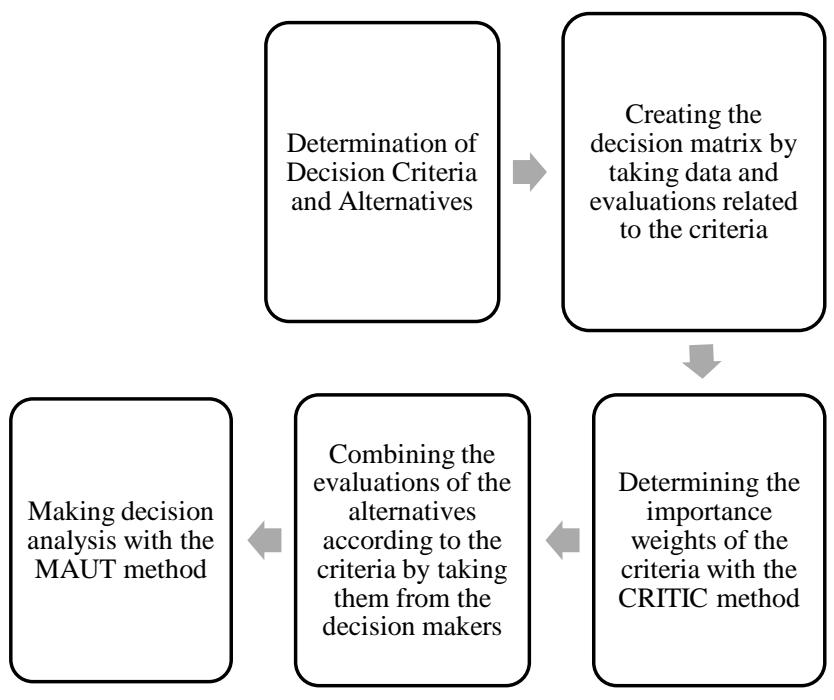

Figure 1. Steps of the decision-making process.

The criteria used in the study and effective in machine selection were determined as a result of literature review and expert opinions. The criteria that are effective in choosing a flat knitting machine are determined as price, the number of Saddle knitting, accessibility to the pattern programmer, accessibility to qualified employees who can use the machine, availability to spare parts, service speed, and facilities, energy consumption. Decision criteria consist of quantitative and qualitative criteria. The values obtained by alternatives according to quantitative criteria were obtained from the product promotion catalogs of the companies. The values related to the qualitative criteria were obtained by using the 1-7 Likert scale with the engineers and technical staff in the manager position of the manufacturing enterprises. It is important to demonstrate the advantages and disadvantages of flat knitting machines in practice that the values related to qualitative criteria are taken from expert technical personnel. The decision criteria used in choosing a flat knitting machine are encoded and given in Table 2.
Table 2. Criteria and weights of criteria in the flat knitting machine selection.

\begin{tabular}{lll}
\hline Code & Criteria & $\begin{array}{l}\text { Nature of } \\
\text { Criteria }\end{array}$ \\
\hline K1 & Price & Cost \\
\hline K2 & Number of saddle weaves & Benefit \\
\hline $\mathbf{K 3}$ & Access to pattern programmer & Benefit \\
\hline $\mathbf{K 4}$ & $\begin{array}{l}\text { Access qualified personel to use } \\
\text { the machine }\end{array}$ & Benefit \\
\hline K5 & Availability of spare parts & Benefit \\
\hline K6 & Service oppotunities & Benefit \\
\hline K7 & Energy Consumption & Cost \\
\hline
\end{tabular}

\subsection{CRITIC Method}

The CRiteria Importance Through Intercriteria Correlation (CRITIC) method is a multi-criteria decision-making method developed by Diakoulaki et al. (1995). The CRITIC method is a recommended method for weighting criteria. The method is one of the objective weighting methods. In the CRITIC method, criteria are weighted according to the data in the decision matrix, without relying on expert opinions and decision-maker preferences. In this method, it uses the standard deviation values and correlation coefficients of the criteria to determine the relationships between the criteria. In the decision matrix, the values of the alternatives according to the quantitative criteria were obtained by measurement. The values that the alternatives will receive according to the qualitative criteria are obtained by the decision makers' evaluation of the alternatives according to the criteria. Evaluations obtained from matrix values according to qualitative criteria are obtained by transforming them into quantitative values. The steps of the CRITIC method can be shown as follows (Alinezhad and Khalili, 2019:199-201, Hassan, Kamal, Moniruzzaman, Zulkifli, and Yusop, 2015).

The first step in the CRITIC method is the generate of the decision matrix. The decision matrix in size of mxn, which contains alternatives and criteria created by decision-makers, is also shown in Equation (1):

$$
M=\left[\begin{array}{ccccc}
x_{11} & \ldots & x_{1 j} & \ldots & x_{1 n} \\
\vdots & \ddots & \vdots & \ddots & \vdots \\
x_{i 1} & \cdots & x_{i j} & \cdots & x_{i n} \\
\vdots & \ddots & \vdots & \ddots & \vdots \\
x_{m 1} & \ldots & x_{m j} & \cdots & x_{m n}
\end{array}\right] ; \quad i=1,2, \ldots m, \quad j=1,2, \ldots n
$$


The $x_{i j}$ value in the decision matrix shows the value taken by the alternative $i$. according to criterion $j$. After the decision matrix is created, The Matrix is normalized. The benefit qualified and cost qualified criteria in the decision matrix is normalized by the formula (2) and (3), respectively.

$$
\begin{aligned}
& r_{i j}=\frac{x_{i j}-x_{j}^{\min }}{x_{j}^{\max }-x_{j}^{\min }} \\
& r_{i j}=\frac{x_{j}^{\max }-x_{i j}}{x_{j}^{\max }-x_{j}^{\min }}
\end{aligned}
$$

As a result of the calculation, $r_{i j}$ values are normalized values of $x_{i j}$ values. After the normalized decision matrix is created, the standard deviation is calculated with correlation coefficients between criteria so that the importance weights of the criteria can be calculated. The weights of the criteria are calculated by the formula (4).

$$
w_{j}=\frac{C_{j}}{\sum_{i=1}^{n} C_{j}} ; i=1,2, \ldots . n
$$

In the formula, $w_{j}$ indicates the importance weight of criterion $\mathrm{j}$, in other words, the degree of importance and priority. $\mathrm{Cj}$ indicates the index value of criterion $\mathrm{j}$.

$$
C_{j}=\sigma_{j} \sum_{k=1}^{n}\left(1-p_{j k}\right) \quad j=1.2, \ldots . . n
$$

In the formula (5), shows the standard deviation of criterion $\mathrm{j}$ and the correlation coefficient between the criteria. The standard deviation of each criterion is calculated by equation (6).

$$
\begin{gathered}
\sigma_{j}=\sqrt{\frac{1}{n-1} \sum_{j=1}^{n}\left(x_{i j}-\bar{x}\right)^{2}} ; \quad i=1,2, \ldots . m \\
p_{j k}=\frac{\sum_{i=1}^{m}\left(x_{i j}-\bar{x}_{j}\right)\left(x_{i k}-\bar{x}_{k}\right)}{\sqrt{\sum_{i=1}^{m}\left(x_{i j}-x_{j}\right)^{2} \sum_{i=1}^{m}\left(x_{i k}-\bar{x}_{k}\right)^{2}}}
\end{gathered}
$$

In Equation (7) and indicates the average of the criteria.

\subsection{MAUT Method}

The MAUT method was developed by Keeney and Raiffa (1976). The method can be used to solve decision problems that have both quantitative and qualitative criteria. The Maut method is a method that analyzes alternatives based on benefit values derived from criteria. In the method, a utility value is calculated for each alternative according to the determined criteria. In the MAUT method, it is aimed that the alternatives obtain the highest total utility value and ranking is made according to these utility values. The application steps of the method can be summarized as follows. (Ishizaka and Nemery 2013; Alinezhad and Khalili, 2019; Tzeng and Huang, 2011).

First, the decision matrix is created.

$$
X=\left[\begin{array}{ccccc}
x_{11} & \ldots & x_{1 j} & \ldots & x_{1 n} \\
\vdots & \ddots & \vdots & \ddots & \vdots \\
x_{i 1} & \cdots & x_{i j} & \cdots & x_{i n} \\
\vdots & \ddots & \vdots & \ddots & \vdots \\
x_{m 1} & \ldots & x_{m j} & \cdots & x_{m n}
\end{array}\right]_{m x n} ; 1=1,2 \ldots . m, \quad j=1,2 \ldots n
$$

In the decision matrix, $\mathrm{x} \_\mathrm{ij}$ indicates the value of the alternative $\mathrm{i}$ according to criteria $\mathrm{j}$. After the decision matrix is created, the values of the alternatives for the utility criterion in the decision matrix are normalized with formula (9). The values of the alternatives for the cost-qualified criteria are normalized using the formula (10) shows the normalized values of the decision matrix.

$$
\begin{aligned}
& r_{i j}=\frac{x_{i j}-x_{i j}^{\min }}{x_{i j}^{\max }-x_{i j}^{\min }} \\
& r_{i j}=1+\frac{x_{i j}^{\min }-x_{i j}}{x_{i j}^{\max }-x_{i j}^{\min }}
\end{aligned}
$$

After the decision matrix is normalized, the utility values of the alternatives are calculated. The utility values are calculated by equation (11).

$$
U_{i}=\sum_{j=1}^{n} u_{i j} \cdot w_{j} ; \quad i=1,2, \ldots . . m
$$

The indicates the utility values and indicates the importance weight of the criterion $\mathrm{j}$. The sum of the importance weights of the criteria is $\sum W_{j}=1$. The utility values of the alternatives are sorted in descending order for the final ranking. The alternative with the highest total utility value is the best.

\section{Application}

In the application section, the CRITIC method was used in determining the weights of decision criteria for determining the most suitable machine, and the MAUT method was used in sorting and selecting alternatives. With the proposed CRITIC and MAUT integrated decision model, a survey was conducted with the engineers and technical staff of the companies operating in the textile sector to choose a flat knitting machine. A survey was conducted by interviewing a total of 40 experts in the positions of managers and technical personnel. With the literature review and interviews, 4 flat knitting machine brands were determined as an alternative. Electronic machines selected in the study were coded as M1, M2, M3, M4. Experts were asked to evaluate alternatives according to qualitative criteria. These criteria are "access to the pattern programmer", "finding qualified personnel to use the machine", "accessibility to spare parts and service possibilities". In the survey, experts were asked to evaluate the alternatives for these criteria on a 1-7 Likert scale. The decision matrix was formed by taking the arithmetic average of the expert evaluations. The values obtained by the alternatives according to the quantitative criteria of "price", "number of saddle weaves" and "electricity consumption" were obtained from the manufacturing companies. The decision matrix created is given in Table 3 . Since the "price" (K1) and "electricity consumption" (K7) criteria in the decision matrix are cost criteria, the values of these criteria are desired to be the 
smallest, while the benefit criteria are requested to have the highest value.

The correlation coefficients between the criteria are calculated by the formula (7).

\section{Tablo 3. The Decision Matrix}

\begin{tabular}{llllllll}
\hline & K1(\$) & K2 & K3 & K4 & K5 & K6 & $\begin{array}{l}\text { K7 } \\
\text { (Kw) }\end{array}$ \\
\hline M1 & 38,000 & 3 & 4,900 & 4,660 & 5,540 & 5,250 & 2,3 \\
\hline M2 & 32,500 & 2 & 6,030 & 5,950 & 6,300 & 6,270 & 1,2 \\
\hline M3 & 32,000 & 2 & 2,090 & 2,090 & 1,900 & 2,040 & 1,5 \\
\hline M4 & 16,500 & 3 & 2,090 & 1,750 & 1,610 & 1,800 & 0,6 \\
\hline
\end{tabular}

After the decision matrix was created, the weights of the criteria were calculated with the CRITIC method. Equation (6) was used to calculate the standard deviation values. The normalized decision matrix is calculated with equality (2) and equality (3) and shown in Table 4.

Table 4. Standard deviation values of criteria and Normalized decision matrix

\begin{tabular}{llllllll}
\hline & K1 & K2 & K3 & K4 & K5 & K6 & K7 \\
\hline M1 & 0 & 1 & 0.713 & 0.692 & 0.837 & 0.771 & 0 \\
\hline M2 & 0.255 & 0 & 1 & 1 & 1 & 1 & 0.647 \\
\hline M3 & 0.279 & 0 & 0 & 0.080 & 0.061 & 0.053 & 0.470 \\
\hline M4 & 1 & 1 & 0 & 0 & 0 & 0 & 1 \\
\hline Std. & 0.429 & 0.577 & 0.508 & 0.483 & 0.517 & 0.505 & 0.415 \\
Dev. & & & & & & & \\
\hline
\end{tabular}

After calculating the normalized decision matrix and standard deviation values, the correlation matrix between the criteria was calculated and given in Table 5.

Table 5. The Correlation coefficients between criteria.

\begin{tabular}{cccccccc}
\hline & K1 & K2 & K3 & K4 & K5 & K6 & K7 \\
\hline K1 & 1 & 0.312 & -0.612 & -0.645 & -0.683 & -0.659 & 0.902 \\
\hline K2 & 0.312 & 1 & -0.162 & -0.231 & -0.124 & -0.161 & -0.081 \\
\hline K3 & -0.612 & -0.162 & 1 & 0.997 & 0.993 & 0.997 & -0.409 \\
\hline K4 & -0.645 & -0.231 & 0.997 & 1 & 0.990 & 0.996 & -0.421 \\
\hline K5 & -0.683 & -0.124 & 0.993 & 0.990 & 1 & 0.998 & -0.510 \\
\hline K6 & -0.659 & -0.161 & 0.997 & 0.996 & 0.998 & 1 & -0.466 \\
\hline K7 & 0.902 & -0.081 & -0.409 & -0.421 & -0.510 & -0.466 & 1 \\
\hline
\end{tabular}

After calculating the correlation coefficients between the criteria, the importance weights of the criteria were calculated by using the equation (3.4) and given in Table 6.

Table 6. Criteria and weights of criteria in the flat knitting machine selection.

\begin{tabular}{lll}
\hline Code & Criteria & Weight of Criteria \\
\hline K1 & Price & 0,172 \\
\hline K2 & Number of saddle weaves & 0,202 \\
\hline K3 & Access to pattern programmer & 0,115 \\
\hline K4 & $\begin{array}{l}\text { Access qualified personel to use the } \\
\text { machine }\end{array}$ & 0,113 \\
\hline K5 & Availability of spare parts & 0,121 \\
\hline K6 & Service oppotunities & 0,117 \\
\hline K7 & Energy Consumption & 0,157 \\
\hline
\end{tabular}

When the criteria weights are examined, it is seen that the importance weights of the criteria are close to each other and there is no big weighting difference between them. However, it is seen that the most important and priority criterion is the number of saddle knitting in flat knitting machines. In addition, it is seen that the criteria of accessibility to the pattern programmer, finding qualified personnel who can use the machine, and access to spare parts are very close to each other and less important in order of importance compared to other criteria. Price, the number of saddle weaves, and electricity consumption was the standout criteria.

After determining the criterion weights by the CRITIC method, the decision matrix was created for choosing a flat knitting machine among 4 brands by the MAUT method. The evaluation of alternatives by engineers, managers, and other technical personnel according to the criteria was combined by taking the arithmetic mean. The decision matrix created is shown in Table 7 .

Table 7. The Decision Matrix

\begin{tabular}{llllllll}
\hline & K1(\$) & K2 & K3 & K4 & K5 & K6 & K7(Kw) \\
\hline M1 & 38,000 & 3 & 4,900 & 4,660 & 5,540 & 5,250 & 2,3 \\
\hline M2 & 32,500 & 2 & 6,030 & 5,950 & 6,300 & 6,270 & 1,2 \\
\hline M3 & 32,000 & 2 & 2,090 & 2,090 & 1,900 & 2,040 & 1,5 \\
\hline M4 & 16,500 & 3 & 2,090 & 1,750 & 1,610 & 1,800 & 0,6 \\
\hline Min & $\mathbf{1 6 , 5 0 0}$ & $\mathbf{2}$ & $\mathbf{2 , 0 9 0}$ & $\mathbf{1 , 7 5 0}$ & $\mathbf{1 , 6 1 0}$ & $\mathbf{1 , 8 0 0}$ & $\mathbf{0 , 6}$ \\
\hline Max & $\mathbf{3 8 , 0 0 0}$ & $\mathbf{3}$ & $\mathbf{6 , 0 3 0}$ & $\mathbf{5 , 9 5 0}$ & $\mathbf{6 , 3 0 0}$ & $\mathbf{6 , 2 7 0}$ & $\mathbf{2 , 3}$
\end{tabular}

After determining the objective weights of the criteria, the MAUT method was used for the selection of a flat knitting machine. The decision matrix is normalized using equations (9) and (10). The normalized decision matrix is given in Table 8.

Table 8. Normalized decision matrix according to the MAUT method.

\begin{tabular}{lcllllll}
\hline & K1 & K2 & K3 & K4 & K5 & K6 & K7 \\
\hline M1 & 0 & 1 & 0.713 & 0.692 & 0.837 & 0.771 & 0 \\
\hline M2 & 0.255 & 0 & 1 & 1 & 1 & 1 & 0.647 \\
\hline M3 & 0.279 & 0 & 0 & 0.080 & 0.061 & 0.053 & 0.470 \\
\hline M4 & 1 & 1 & 0 & 0 & 0 & 0 & 1
\end{tabular}

After obtaining the normalized matrix, the total utility values for each alternative were calculated with the equation (11). The utility values of the alternatives are shown in Table 9.

Table 9. Benefit Matrix weighted by CRITIC method.

\begin{tabular}{cccccccc}
\hline & K1 & K2 & K3 & K4 & K5 & K6 & K7 \\
\hline M1 & 0 & 0.202 & 0.082 & 0.078 & 0.101 & 0.090 & 0 \\
\hline M2 & 0.044 & 0 & 0.115 & 0.113 & 0.121 & 0.117 & 0.101 \\
\hline M3 & 0.048 & 0 & 0 & 0.009 & 0.007 & 0.006 & 0.074 \\
\hline M4 & 0.172 & 0.202 & 0 & 0 & 0 & 0 & 0.157
\end{tabular}

The total utility values for the alternatives are obtained by summing the utility values calculated according to each criterion. The calculated total utility values and ranking of the alternatives according to their total utility values are shown in 
Table 10. M2 machine was determined as the best alternative in the ranking made according to the MAUT method. The machines are listed as M2, M1, M4, M3, starting from the best.

Table 10. Ranking of flat knitting machines according to the CRITIC-weighted MAUT method.

\begin{tabular}{ccc}
\hline Machines & Total utility values & Ranking \\
\hline M1 & 0.555 & 2 \\
\hline M2 & 0.614 & 1 \\
\hline M3 & 0.145 & 4 \\
\hline M4 & 0.531 & 3 \\
\hline
\end{tabular}

\section{Results and Discussion}

Decision-making is the process of choosing the most suitable one from among the alternatives. The first step in making the right decision is to define the decision problem and design the process. Decisions can be classified from a variety of care. It is possible to classify decisions as long-term decisions and shortterm decisions in terms of the duration of the decision's impact, in other words, its maturity. From this point of view, constant capital investment decisions in companies are expressed as longterm decisions. Decisions to purchase constant assets, such as machinery and equipment, which are expressed as constant capital investments in companies, are decisions of a strategic nature for companies. The main reason that fixed capital investment decisions are characterized as strategic is that they are the basic requirement of low-cost and efficient production. Second, constant capital investment decisions are rarely decisions made, unlike working capital decisions, and are not open to changes and corrections. For this reason, machine purchase decisions involving long-term investments should be analyzed using scientific and appropriate methods and should be true. In this context, it is seen that decisions to purchase flat knitting machines for textile enterprises are strategic and longterm decisions.

Decision problems that require the consideration of a large number of contradictory criteria are solved by multi-criteria decision-making methods. The profitability and continuity of the business need to decide to purchase flat knitting machines with the problem of MCDM using scientific methods. In this study, the most suitable flat knitting machine was selected with CRITIC and MAUT methods, which are among the multicriteria decision-making methods for a textile company. The selection of a flat knitting machine is a decision problem in which many conflicting criteria are effective. In this study, the importance weights of the criteria were determined by the CRITIC method, and the machine selection and evaluation were made with the MAUT method. In the study, the best of 4 falt knitting machines were determined according to 7 criteria evaluation criteria, 4 of which were qualitative and 3 of which were quantitative. According to the ranking made by the MAUT method, the M' machine was determined as the best alternative. The machines are listed as M2, M1, M4, M3, starting from the best.

\section{Conclusions and Recommendations}

CRITIC method is characterized as objective weighting method. The method uses values in the decision matrix without the need for expert or decision-maker opinions when determining the importance weights of criteria. As with the criteria affecting the decision of choosing a flat knitting machine, the situation may arise when the decision criteria in decision problems cannot be determined in terms of their superiority over each other in terms of their weight of importance. In such cases, the CRITIC method seems to provide a solution by overcoming the uncertainty experienced in weighting. In this sense, according to the results of the study, it was concluded that the CRITIC method is a method that provides an objective solution, taking into account the uncertainty experienced in setting the priorities of two or more criteria. The Maut method used in sorting alternatives in the study evaluates alternatives based on the total benefit function. In the method, the total benefit value is reached by collecting the calculated benefit values for alternatives according to each criterion. According to the results of the study, it was concluded that the Maut method is an easy-to-understand and viable method. It was concluded that CRITIC and MAUT methods used in the study are integrated methods that can be used to solve machine selection problems. As with the machine purchase problem, making comparisons using different MCDM methods in solving decision problems that involve uncertainty in determining criterion weights will enrich the literature and contribute.

\section{References}

Akın, N. G. (2019). Makine Seçimi Probleminde ENTROPİ ROV ve CRITIC - ROV Yöntemlerinin Karşılaștırılması. Dumlupınar Üniversitesi Sosyal Bilimler Dergisi, 62, 20-39.

Alinezhad, A. \& Khalili, J. (2019). New Methods and Applications in Multiple Attribute Decision Making (MADM). International Series in Operations Research and Management Science

Bošković, S., Radonjić-djogatović, V., Ralević, P. \& Dobrodolac, M., Jovcic S.,(2021). Selection Of Mobile Network Operator Using The CRITIC-ARAS Method, International Journal for Traffic and Transport Engineering11(1), 17-29.

Bulğurcu, B. (2019). Çok Nitelikli Fayda Teorisi ile CRITIC Yöntem Entegrasyonu: Akıllı Teknoloji Tercih Örneği. OPUS Uluslararası Toplum Araştırmaları Dergisi, 13(19), 1931-1951.

Chan, E. H., Suen, H. C., \& Chan, C. K. (2006). MAUT-based dispute resolution selection model prototype for international construction projects. Journal of construction engineering and management, 132(5), 444-451.

Diakoulaki, D., Mavrotas, G. \& Papayannakis, L. (1995). Determining objective weights in multiple criteria problems: The critic method. Computers and Operations Research, 22(7), 763-770.

Ertuğrul, İ., \& Öztaş, T. (2015). The application of sewing machine selection with the multi-objective optimization on the basis of ratio analysis method (MOORA) in apparel sector. Textile and Apparel, 25(1), 80-85.

Ertuğrul, İ. (2007).Bulanık Analitik Hiyerarşi Süreci ve Bir Tekstil İşletmesinde Makine Seçim Problemine Uygulanmas1. H.Ü. İktisadi ve İdari Bilimler Fakültesi Dergisi, 25(1), 171-192.

Eş, A. \& Kocadağ, D. (2020). Entropy Tabanlı MAUT ve VIKOR Yöntemleriyle Tedarikçi Seçimi: Bir Kamu Kurumu Örneği. Celal Bayar Üniversitesi Sosyal Bilimler Dergisi, 18, 265-280.

Hassan, N., Kamal, Z., Moniruzzaman, A. S., Zulkifli, S. \& Yusop, B. (2015). Weighting Methods and their Effects on 
Multi-Criteria Decision Making Model Outcomes in Water Resources Management. Springer.

Tzeng, G.-H. \& Huang J.-J. (2011). Multiple Attribute DecisionMaking $\mathrm{M}$ e $\mathrm{t} \mathrm{h}$ o d s a n d a p $\mathrm{lic}$ a t i o n s. CRC Press Taylor \& Francis Group.

Ishizaka, A. \& Nemery, P. (2013). Multi-Criteria Decision Analysis. Wiley.

Li, H., Wang, W., Fan, L., Li, Q. \& Chen, X. (2020). A novel hybrid MCDM model for machine tool selection using fuzzy DEMATEL, entropy weighting, and later defuzzification VIKOR. Applied Soft Computing Journal, 91, 106207.

Orhan, M., \& Aytekin. M. (2020). Türkiye İle AB'ye Son Katılan Ülkelerin Ar-Ge Performanslarının CRİTíC Ağırlıklı MAUT VE SAW Yöntemiyle Kıyaslanması. Busıness \& Management Studies: An International Journal, 8(1), 754778.

Özceylan, E., Kabak, M., \& Dağdeviren, M. (2016). A fuzzybased decision-making procedure for machine selection problem. Journal of Intelligent \& Fuzzy Systems, 30(3), 1841-1856.

Özdağoğlu, A. \& Çirkin, E. (2019). Electronic Device Selection in Industrial Products and Machinery Industry: Comparative Analysis With Ocra and Maut Method. International Journal of Contemporary Economics and Administrative Sciences, 9(1), 119-134.

Stirbanovic, Z., Stanujkić, D., Miljanović, I. \& Milanović, D. (2019). Application of MCDM methods for flotation machine selection. Minerals Engineering, 137(April), 140146.

Ulutaş, A. (2017). EDAS Yöntemi Kullanılarak Bir Tekstil Atölyesi İçin Dikiş Makinesi Seçimi - Sewing Machine Selection for a Textile Workshop by Using EDAS Method. Journal of Business Research - Turk, 9(2), 169-183.

Ulutaş, A., \& Cengiz, E. (2018). CRITIC ve EVAMIX Yöntemleri İle Bir İşletme İçin Dizüstü Bilgisayar Seçimi. Journal of International Social Research, 11(55).

Ulutaş, A. (2017). EDAS Yöntemi Kullanılarak Bir Tekstil Atölyesi İçin Dikiş Makinesi Seçimi - Sewing Machine Selection for a Textile Workshop by Using EDAS Method. Journal of Business Research - Turk, 9(2), 169-183.

Vargün, H., \& Doğan. M. (2020). Muhasebe Birimi Personel Seçim Problemi: Entropi Temelli Maut Yöntemi Uygulaması. Mali Çözüm İSMMO, 30(162), 177-191.

Wu, Z., Ahmad, J., \& Xu, J. (2016). A group decision-making framework based on fuzzy VIKOR approach for machine tool selection with linguistic information. Applied Soft Computing, 42, 314-324.

Yalçın, N. \& Karakaş, E. (2019). Kurumsal Sürdürülebilirlik Performans Analizinde CRITIC-EDAS Yaklaşımı CRITICEDAS Approach in Corporate Sustainability Performance Analysis. Çukurova Üniversitesi Mühendislik Mimarlık Fakültesi Dergisi, 34(December), 147-161.

Yürük, M. F. \& Orhan, M. (2020). CRITIC ve ENTROPİ Temelli MAUT Yöntemi ile İmalat Sanayi Alt Sektörlerinin Finansal Performanslarının Analizi. Munzur Üniversitesi Sosyal Bilimler Dergisi, 9(2), 151-172.

Zeydan, M., Bostancı, B., Oralhan, B., Eroğlu, D., \& Aydıner, U. (2020). Mekânsal Bulanık Karar Destek Sisteminin Geliştirilmesi. Avrupa Bilim ve Teknoloji Dergisi, 418-429. 